\title{
Anti-Cancer Potential of Nggorang Leaves Extract (Salvia Occidentalis SW.) as a Protein P53 Supressor in T47D Cells
}

\author{
Sisilia Teresia Rosmala Dewi' ${ }^{1}$ M. Sabir ${ }^{2}$, Sesilia Rante Pakadang ${ }^{1}$, Sainal Edi Kamal ${ }^{3}$, Santi Sinala ${ }^{1, *}$
}

Sisilia Teresia Rosmala Dewi', M. Sabir ${ }^{2}$, Sesilia Rante Pakadang ${ }^{1}$, Sainal Edi Kamal ${ }^{3}$, Santi Sinala ${ }^{1, *}$

${ }^{1}$ Health Polytechnic of the Makassar Ministry of Health, INDONESIA

${ }^{2}$ Faculty of Medicine University of Tadulako Palu, INDONESIA.

${ }^{3}$ Polytechnic Sandi Karsa Makassar, INDONESIA.

\section{Correspondence}

\section{Santi Sinala}

Health Polytechnic of the Makassar Ministry of Health, INDONESIA.

E-mail: santisinala@poltekkes-mks.ac.id

History

- Submission Date: 19-03-2021;

- Review completed: 29-04-2021;

- Accepted Date: 01-06-2021.

DOI : 10.5530/pj.2021.13.134

Article Available online

http://www.phcogj.com/v13/i4

Copyright

(c) 2021 Phcogj.Com. This is an openaccess article distributed under the terms of the Creative Commons Attribution 4.0 International license.

\begin{abstract}
Breast cancer is one of the most common types of cancer in women. The high incidence of breast cancer has led to the development of anticancer drugs that are more selective against cancer cells without damaging normal tissues. One of the alternatives in cancer treatment by looking for natural sources that can be developed, Nggorang leaves (Salvia occidentalis Sw.). This plant is found in Tenda Village, Langke Rembong District, Manggarai Regency, NTT Province, when the leaves are harvested for one year and are used as medicine. As a preventive, this leaf has been used for generations as an anticancer (7 leaves boiled with $200 \mathrm{ml}$ of water to $100 \mathrm{ml}$ and then drunk), for wounded breast cancer (crushed leaves and attached to the wound); stamina enhancer, cough, influenza, hemorrhoids, diarrhea, nosebleeds (Primary data, 2014). This study aims to prove the potential of EDG (Nggorang Leaves Extract) as an antiproliferative against Hela cancer cells and protein P53 suppressor. The method used is the Quasy experiment, because this study uses laboratory tests in sample testing. The results of the cytotoxic test of Nggorang Leaves Extract have the potential to be anti-proliferative against cancer cells T47D IC50 at $201 \mathrm{ppm}$ and Nggorang Leaves Extract (EDG) has the potential to increase p53 gene suppression in T47D cancer cells by $94.13 \%$ at a concentration of $50 \mathrm{ppm}$.

Key words: Anticancer, Nggorang Leaves Extract (Salvia occidentalis Sw), T47D, Protein P53.
\end{abstract}

\section{INTRODUCTION}

Indonesia is one of the countries with the largest biodiversity in the world which has more than 3000 species of tall plants. Until now, 7000 plant species have been recorded for their known properties. However, less than 300 plants are used as ingredients in the pharmaceutical industry on a regular basis. About 1000 plants have been identified from the botanical aspects of plant systematics as well ${ }^{1}$. Medicinal plants have been widely used by humans since ancient times and are even believed to have more potent properties than doctor's medicines. However, due to the development of the times and the increasing knowledge of humans about pharmacology and medical science, many people have turned to medical medicine because they believe more in chemical drugs that have been tested for their efficacy in the laboratory, compared to traditional medicines that many cannot be proven laboratoryally ${ }^{2}$.

Cancer is the second leading cause of death globally, accounting for an estimated 9.6 million deaths, or one in six deaths, in 2018. Lung, prostate, colorectal, stomach and liver cancer is the most common type of cancer in men, whereas breast cancer is the most common type of cancer. colorectal, lung, cervical and thyroid cancer are the most common among women ${ }^{3}$. Several ways of treating cancer in humans, namely radiotherapy, chemotherapy, the use of chemical drugs, and herbs. Among the methods of treatment, the use of herbal medicine is expected to be an alternative solution to the high side effects of radiotherapy, chemotherapy, and the use of chemical drugs. Therefore, from time to time testing the use of plants as an antiproliferative against apoptosis of cancer cells is carried out.
Nggorang leaves (Salvia occidentalis Sw.) Lamiaceae family has the potential as an anticancer. Damaris research (2019) ${ }^{4}$ entitled Identification of the Chemical Content of Nggorang Leaves (Salvia occidentalis Sw.) Using a GC-MS Spectrophotometer. The results of research using GC-MS were obtained, namely Terpenoida, Palmitic Acid, Steroids, Phytol, Chlorophyll, Beta Carotene, Vitamin A, Alcohol, Phenolic Acid, Testosterone, Prednisolone.

p53 is a gene suppressor tumor that functions as a determinant of genes by playing on the main pathway to determine DNA damage and determine whether the cell must perform DNA repair against existing DNA damage or stimulate cells to undergo the apoptosis process. Mutant p53 loses the function of wild-type p53, resulting in excessive cell proliferation due to DNA damage so that cells can be transformed into malignant cells. More than $50 \%$ of the primary tumors in humans are missing the $\mathrm{p} 53$ wil type gene suppressor tumor even showing a rapid increase of mutant p53 levels. To achieve the aim of these studies in the long term control the activation of wild type p53 in normal cells and if wild type p53 is lost in tumor cell development ${ }^{5}$.

In the event of apoptosis, the p53 gene is expressed when there is DNA damage so that an error occurs in the cell cycle, namely the p53 gene induces cell cycle arrest. This is so that the DNA damage in the damaged cells has time to be repaired. However, if the damage cannot be repaired, the p53 gene expression will increase so that it will trigger the apoptosis of T47D cells ${ }^{6}$. Conversely, if the p53 gene is not expressed in cells, a mutation occurs in p53 so that the gene becomes unstable and subsequently has the potential to become cancer. The p53 gene is an apoptotic signal because it suppresses tumor

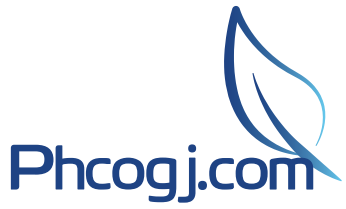

Cite this article: Dewi STR, Sabir M, Pakadang SR, Kamal SE, Sinala S. Anti-Cancer Potential of Nggorang Leaves Extract (Salvia Occidentalis SW.) as a Protein P53 Supressor in T47D Cells. Pharmacogn J. 2021;13(4): 1036-1045. 
formation and inhibits malignant progression. The mechanism that occurs in cells is that the p53 gene eliminates cells that have DNA damage that has the potential to become cancer cells by means of cell cycle arrest, apoptosis or repair ${ }^{7}$.

Although it has been used empirically by the Manggarai community for anticancer treatment, scientific evidence does not yet exist. So that the leaves of Nggorang (Salvia occidentalis $\mathrm{Sw}$ ) are very potential to be researched and developed considering that cancer cases in Indonesia are still very high. The purpose of this study was to analyze the effect of giving EDG as an antiproliferation against T47D cancer cells with the MTT method and to analyze the effect of EDG on the increase of P53 suppressor in T47D cancer cells.

\section{MATERIALS AND METHODS}

\section{Materials}

The research materials used were Nggorang leaves extract, materials for cytotoxicity activity in the form of T47D cancer cell culture, Doxorubicin, medium RPMI 1640, bovine serum albumin (BSA), penicillin-streptomycin, $\mathrm{N}$-2-hydroxyethilpiperazine-2-ethanesuffonic acid (hepes), NaHCO3, fungizone (Amphotein B), 13- (4,5-dimethyl thiazol 2-yl-2,5-diphenyl tetrazolium bromide (MTT); sodium dodecyl sulphate (SDS), dimethyl sulfoxide (DMSO), trypsin-EDTA, buffer phosphate $\mathrm{pH}$ 7,4 and methylene blue; materials for apoptosis and cell cycle analysis: reagent flow chart and PI / RNase Staining buffer kit. Cancer cells T47D, Hela and normal Vero cells were obtained from the Parasitology Department, Faculty of Medicine UGM. All cells were grown on the appropriate medium in a flash disk culture. All mediums were given a supplement of BSA $10 \%$, penicillin-streptomycin $1 \%$ and fungizone $0.5 \%$. The cells in the flash culture disk were incubated at $37^{\circ} \mathrm{C}$ with $5 \% \mathrm{CO}_{2}$ gas flow. Cell proliferation is observed under an inverted microscope and confluent cells (80-90\%) are harvested.

\section{Methods}

This research is a quasi-experimental research, because this research uses laboratory tests in sample testing. The anticancer potential of Nggorang leaves extract (Salvia occidentalis Sw.) which includes cytotoxicity and working mechanism tests is an experimental study with an exploratory design and $\mathrm{p} 53$ expression testing, an experimental study with a posttest only design with a control group test. The experimental units were cancer cells T47D, Hela and Doxorubin obtained from Parasitology and Pathology of Anatomy, Faculty of Medicine UGM.

The number of groups in this study was 14 groups. Each group received a different test material treatment as follows:

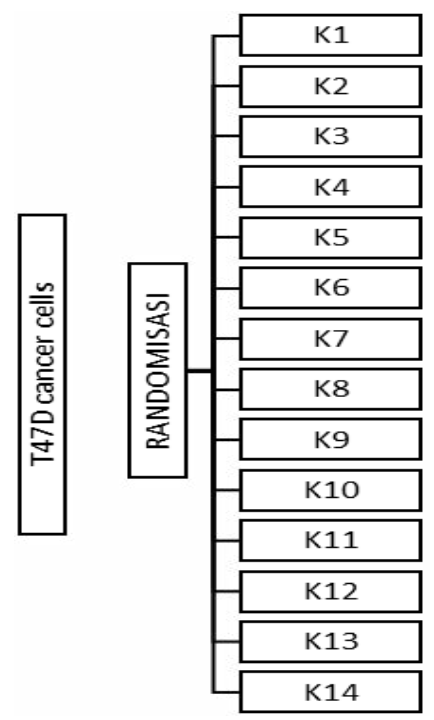

Caption:

$\mathrm{K} 1=$ Giving EDG with a concentration of $1.5625 \mu \mathrm{g}$ on Doxorubicin

$\mathrm{K} 2=$ Administration of EDG with a concentration of $3.125 \mu \mathrm{g}$ on Doxorubicin

$\mathrm{K} 3$ = Administration of EDG with a concentration of $6.25 \mu \mathrm{g}$ on Doxorubicin

$\mathrm{K} 4=$ Administration of EDG with a concentration of $12.5 \mu \mathrm{g}$ on Doxorubicin

$\mathrm{K} 5=$ Administration of EDG with a concentration of $25 \mu \mathrm{g}$ on Doxorubicin

K6 = Administration of EDG with a concentration of $50 \mu \mathrm{g}$ on Doxorubicin

$\mathrm{K} 7=$ Administration of EDG with a concentration of $100 \mu \mathrm{g}$ on Doxorubicin

$\mathrm{K} 8=$ Administration of EDG with a concentration of $15.625 \mu \mathrm{g}$ on T47D cancer cells

K9 $=$ Administration of EDG with a concentration of $31.25 \mu \mathrm{g}$ on T47D cancer cells

$\mathrm{K} 10=$ Administration of EDG with a concentration of $62.5 \mu \mathrm{g}$ on T47D cancer cells

K11 = Administration of EDG with a concentration of $125 \mu \mathrm{g}$ on T47D cancer cells

$\mathrm{K} 12=$ Administration of EDG with a concentration of $250 \mu \mathrm{g}$ on T47D cancer cells

$\mathrm{K} 13=$ Administration of EDG with a concentration of $500 \mu \mathrm{g}$ on T47D cancer cells

K14 $=$ Administration of EDG with a concentration of $1000 \mu \mathrm{g}$ on T47D cancer cells

\section{CYTOTOXICITY ACTIVITY TEST}

\section{Sample Testing with the MTT Method}

A cell suspension of $100 \mu \mathrm{I}\left(1 \times 10^{4}\right.$ cells / $\left.100 \mu \mathrm{L}\right)$ was inserted into the 96 well microplate, unless the control medium contained no cell suspension, then incubated in an incubator at $37^{\circ} \mathrm{C}$ with $5 \% \mathrm{CO}_{2}$ flow for 24 hours. After 24 hours, the cells were observed under a microscope. The sample contains $100 \mu \mathrm{L}$ of cell suspension and $100 \mu \mathrm{L}$ of samples with various concentration variations; control cell contains $100 \mu \mathrm{L}$ of cell suspension and $100 \mu \mathrm{L}$ of medium, control medium contains $200 \mu \mathrm{L}$ of medium, control of doxorubicin contains $100 \mu \mathrm{L}$ of doxorubicin concentration series and $100 \mu \mathrm{L}$ of cell suspension, control DMSO contains DMSO and $100 \mu \mathrm{L}$ of cell suspension. Incubation was carried out for 24 hours at $37^{\circ} \mathrm{C}$ with a flow of $5 \% \mathrm{CO}_{2}$.

After 24 hours of incubation, all contents of the microplate were removed and filled with $100 \mu \mathrm{L}$ of MTT solution $(5 \mathrm{mg} / \mathrm{mL})$, then incubated again for 4 hours. After incubation, $100 \mu \mathrm{L}$ of $10 \%$ SDS was added, then incubated 24 hours at room temperature. The absorbance was read with an ELISA reader at a wavelength of $595 \mathrm{~nm}$, so that the absorbance value data were obtained from all treatments.

The absorbance measurement data were analyzed for the percentage of inhibition against cells using the following equation:

Percent inhibition $=\frac{\text { A control }- \text { A sample }}{\text { A control }} \times 100 \%$

The $\mathrm{IC}_{50}$ value, which is a sample cytotoxicity parameter is determined through probit analysis, while the selectivity index (SI) is determined by the formula: 
$S I=\frac{\text { IC50 Normal Cells }}{\text { IC50 Cancer Cells }}$

\section{P53 Protein Expression Examination (KIT)}

Analysis of p53 protein expression was performed using immunohistochemical (IHC) techniques. A total of $1 \mathrm{ml}$ of cell suspension was inserted into the 24 wells microplate which had previously been coated with coverslip and incubated for 24 hours at 37 ${ }^{\circ} \mathrm{C}$ with $5 \% \mathrm{CO}_{2}$ gas flow. The cells were then washed with PBS pH 7.4 and treated with various concentrations of the ethanol extract of the leaves of Salvia occidentalis Sw. The cells were then incubated again for 24 hours. After 24 hours, the cells were washed with PBS three times until clean. Cells were added with cold methanol for 5 minutes for cell fixation. The fixed cells were washed again with PBS three times until clean and transferred to disk. Cells were added with $10 \%$ hydrogen peroxide and incubated again for 10 minutes. The cells were washed three times with PBS until clean and dried with absorbant paper. Cells were added with serum blocking and incubated again for 30 minutes. The cells were washed three times with PBS until clean and dried with absorbant paper. Cells were added with P53 primary antigen on examination of $\mathrm{P} 53$ protein and incubated for 24 hours at $4^{\circ} \mathrm{C}$. The cells were washed three times with PBS until clean and dried with absorbant paper. Cells were added with secondary antigen and incubated for 30 minutes. The cells were washed three times with PBS until clean and dried with absorbant paper. Cells were added with conjugate HRP and incubated for 10 minutes. The cells were washed three times with PBS until clean and dried with absorbant paper and added with DAB. Cells were incubated for 5 minutes. The stained cells were then washed with aquadest until they were clean and flooded with HE solution and incubated for 15 minutes. Cells are washed under running water to remove excess HE. The cells were dried with absorbant paper and dipped with ethanol stratified starting from $70 \%$ ethanol, $90 \%$ ethanol and $100 \%$ ethanol and finally dyed with xylol. The coverslip containing the cells is then glued together with a stick.

The stained and glued cells were then observed under a light microscope. $\mathrm{P} 53$ protein expression is characterized by a brown color in the cytoplasm and a purple color in the cell nucleus. Histopathological analysis of protein P53 expression was performed by an anatomical pathologist.

The percentage of protein expression is calculated by the formula:

Percent protein expression $=\frac{\text { The Number of Cells Expressing Marker Proteins }}{\text { Total Number of Cells }} \times 100 \%$

\section{DATA ANALYSIS}

The percentage of inhibition data obtained in the antioxidant test and cytotoxicity test then calculated the $\mathrm{IC}_{50}$ by using probit analysis using SPSS software. Data on percent of cell accumulation at each phase of the cell cycle, percent apoptosis, percent expression of $\mathrm{p} 53$ protein were tested for normality by the Shapiro-Wilk test and homogeneity with the Levene test. If the data is normal and the distribution is homogeneous, a one way Anova statistical analysis is performed. If the data is not homogeneously distributed, it is followed by the parametric Anova test and continued with the Mann Whitney test.

\section{RESULT AND DISCUSSION}

\section{Effect of EDG on Cell Viability}

Observation of the inhibition of T47D cell proliferation was carried out using the ELISA method. The results of the Tests of Normality showed the normality of the data from the 9 treatment groups on the T47D cell variable. The data for 9 groups were normally distributed with sig. $0.111-0.969>0.05$ and 1 group with sig. $0.008<0.05$ indicates abnormal data distribution. Homogeneity data shows a sig value of
$0.005<0.05$ indicates that the data is not homogeneous. Since there are data that are not normal and are not homogeneous, the data processing uses the Kruskal-Wallis non-parametric test and is followed by the Mann Whitney test to determine the differences between groups.

The results of the Kruskal-Wallis test showed that there were differences in the data of the treatment group on the T47D variable with a sig. $0.002<0.05$. This means that all treatment groups showed differences in the inhibition of T47D proliferation, so the test was continued using the Mann Whitney test with the results according to table 1.

Table 1 shows that 9 out of 36 data between treatments do not differ in the cell variable T47D with a sig value. $0.146-1,000>0.05$. The results of the Mann-Whitney test showed no difference in the percentage of inhibition of T47D cell proliferation between treatments 1-3.

Figure 1. shows the average percentage inhibition of T47D cell proliferation from each concentration. The bar chart above shows that the low percentage of T47D cell proliferation inhibition occurred in the treatment group with a concentration of $1000 \mu \mathrm{g} / \mathrm{ml}$. The high concentration of T47D cell proliferation inhibition was obtained from a concentration of $7,8125 \mu \mathrm{g} / \mathrm{ml}$.

\section{Doxorubicin}

The observation of Doxorubicin inhibition was carried out using the ELISA method. The results of the Tests of Normality showed the normality of data from 9 treatment groups on the Doxorubicin variable. The data for 9 groups were normally distributed with sig. 0.174 $-0.843>0.05$ and 1 group with sig. $0.000<0.05$ indicates abnormal data distribution. Homogeneity data shows a sig value of $0.073>0.05$ indicating that the data is not homogeneous. Since there are data that are not normal and are not homogeneous, the data processing uses the Kruskal-Wallis non-parametric test and is followed by the Mann Whitney test to determine the differences between groups. The Kruskal-Wallis test results showed that there were differences in the data of the treatment group on the Doxorubicinn variable with a sig. $0.001<0.05$. This means that all treatment groups showed differences

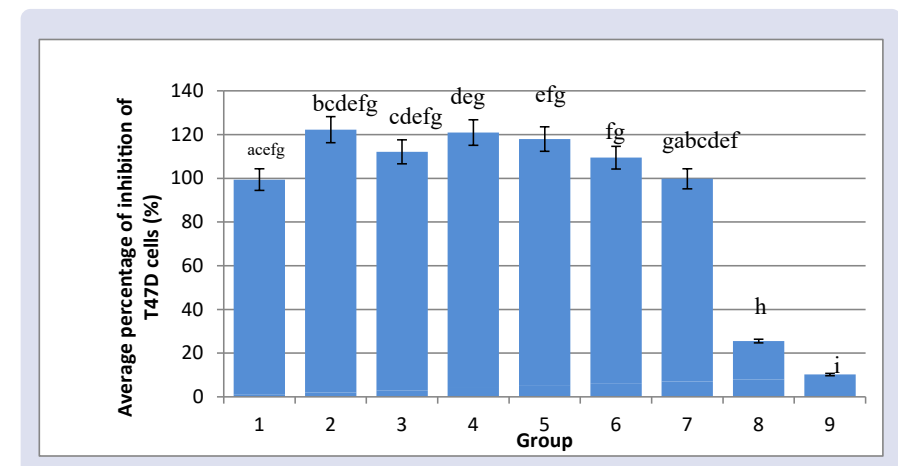

Figure 1: Average percentage inhibition of T47D cells.

Caption:

The same abcdefghi superscript showed no difference between groups (based on the Mann-Whitney test) at $\alpha=0.05$

Group 1: control cells

Group 2: EDG concentration 7,8125 $\mu \mathrm{g} / \mathrm{ml}$

Group 3: EDG concentration of $15.625 \mu \mathrm{g} / \mathrm{ml}$

Group 4: EDG concentration $31.25 \mu \mathrm{g} / \mathrm{ml}$

Group 5: EDG concentration $62.5 \mu \mathrm{g} / \mathrm{ml}$

Group 6 EDG concentration $125 \mu \mathrm{g} / \mathrm{ml}$

Group 7 EDG concentration $250 \mu \mathrm{g} / \mathrm{ml}$

Group 8 EDG concentration of $500 \mu \mathrm{g} / \mathrm{ml}$

Group 9: EDG concentration $1000 \mu \mathrm{g} / \mathrm{ml}$ 
in Doxorubicin inhibition, so the test was continued using the Mann Whitney test with the results according to table 2 .

Table 2 shows that 8 of the 24 data between treatments do not differ on the Doxorubicin variable with a sig value. $0.149-1,000>0.05$. Mann-Whitney test results showed no difference in the amount of Doxorubicin inhibition between treatments.

\section{EDG enhancement on p53 gene expression in T47D cells}

Observation of the increase in p53 gene expression on T47D cells was carried out using the immunocytochemical method (IHC). The results of the Tests of Normality showed the normality of data from 4 treatment groups (negative control; IC10; IC25; IC50) to the T47D cell variable. All groups showed normally distributed data with a sig value. 0.081 $0.959>0.05$. The homogeneity table shows the sig value. $0.017<0.05$ means that the data are not homogeneous. Since the distribution of data is normal but not homogeneous, data processing uses the KruskalWallis non-parametric test and is followed by the Mann Whitney test to determine differences between groups.

The results of the Kruskal-Wallis test showed that there were differences in the data of the treatment group on the variable p53 gene expression enhancement to T47D cells with a sig value. $0.002<0.05$. This means that all treatment groups showed differences in the increase in p53 gene expression on T47D cells so that the test was continued using the Mann Whitney test with the results according to table 3 .
Table 3 shows the Mann-Whitney test results showed that there was no difference in the increase in $\mathrm{p} 53$ gene expression on T47D cells between EDG IC ${ }_{25}$ treatment and $\mathrm{IC}_{50}(\mathrm{p}=0.456)$.

Figure 3 shows that the average increase in p53 gene expression on T47D cells from each treatment group varies. The above bar chart shows that giving the extract concentration correlates with an increase in $\mathrm{p} 53$ gene expression. The greater the concentration, the greater the increase in p53 gene expression.

\section{IC $_{50}$ EDG AGAINST CANCER CELLS}

\section{T47D cells}

Observation of the effect of EDG on the viability of T47D cells was carried out using the ELISA method. The results of cell viability with various incubation periods and $\mathrm{IC}_{50}$ testing of T47D cells given $\mathrm{EDG}$ with various concentrations were obtained according to table 4 and Figure 4 .

Based on table 4 and figure 4 , various $\mathrm{IC}_{50}$ values are obtained. The data showed that the EDG incubation time in T47D cell culture gave different viability results and $\mathrm{IC}_{50}$ values. The longer the incubation period, the smaller the $\mathrm{IC}_{50}$ concentration used to kill T47D cells. The EDG concentration needed to produce $50 \%$ activity after 24 hours incubation obtained $\mathrm{IC}_{50}$ values $373.26 \mu \mathrm{g} / \mathrm{ml}$; After 48 hours of incubation, the $\mathrm{IC}_{50}$ value was $369.75 \mu \mathrm{g} / \mathrm{ml}$; After 72 hours of incubation, the $\mathrm{IC}_{50}$ value was $255.37 \mu \mathrm{g} / \mathrm{ml}$.

Table 1: The results of different tests between treatments based on the Mann-Whitney test on the T47D cell variable.

\begin{tabular}{|c|c|c|c|c|c|c|}
\hline $\begin{array}{l}\text { Consentration } \\
\text { EDG }(\mu \mathrm{g} / \mathrm{ml})\end{array}$ & Mean & $\mathbf{N}$ & Std. Deviation & Median & Minimum & Maksimum \\
\hline Control cell & 100,00 & 4 & 5.11 & $98.41^{\mathrm{ac}}$ & 96.18 & 106.99 \\
\hline 15.625 & 109.80 & 4 & 11.53 & $109.10^{c}$ & 96.65 & 124.37 \\
\hline 31.25 & 115.91 & 4 & 3.28 & $116.97^{\mathrm{ab}}$ & 111.22 & 118.50 \\
\hline 62.5 & 111.33 & 4 & 12.26 & $112.97^{\mathrm{abc}}$ & 95.24 & 124.13 \\
\hline 500 & 27.83 & 4 & 22.75 & $17.49^{\mathrm{a}}$ & 14.45 & 61.89 \\
\hline 1000 & 9.68 & 4 & 2.11 & $10.21^{\mathrm{a}}$ & 6.69 & 11.63 \\
\hline Total & 88.96 & 36 & 41.11 & 103.46 & 6.69 & 159.37 \\
\hline
\end{tabular}

Info: abc the same superscript shows no difference between groups (based on the Mann-Whitney test)

Table 2: Results of the Difference Between Treatments Based on the Mann-Whitney Test on the Doxorubicin Variable.

\begin{tabular}{|c|c|c|c|c|c|c|}
\hline $\begin{array}{l}\text { Consentration } \\
\text { EDG }\end{array}$ & Mean & $\mathbf{N}$ & Std. Deviation & Median & Minimum & Maximum \\
\hline Cell Control & 99,99 & 3 & 1,16 & 99,43 & 99,23 & 101,34 \\
\hline 3,125 & 85,79 & 3 & 1,48 & 85,93 & 84,25 & 87,20 \\
\hline 6,25 & 77,96 & 3 & 1,54 & 77,07 & 77,08 & 79,75 \\
\hline 12,5 & 63,50 & 3 & 2,25 & 63,99 & 61,04 & 65,47 \\
\hline 50 & 29,67 & 3 & 1,71 & 30,45 & 27,71 & 30,87 \\
\hline 100 & 18,49 & 3 & 1,28 & 18,21 & 17,37 & 19,90 \\
\hline Total & 47,09 & 24 & 34,93 & 43,31 &, 00 & 101,34 \\
\hline
\end{tabular}

Table 3: The results of different tests between treatments based on the Mann-Whitney test on the increase in p53 gene expression on T47D cells.

\begin{tabular}{lcccccc|}
\hline $\begin{array}{l}\text { Concentration } \\
\text { EDG }\end{array}$ & Mean & N & Std. Deviation & Minimum & Maximum \\
\hline Negative Control & $\mathbf{2 , 1 9}$ & 5 &, 93 & 1.43 & 3,66 & Median \\
\hline IC 10 & 94,12 & 5 & 3,36 & 89,39 & 98,67 & 94,11 \\
IC 25 & 87,12 & 5 & 5,94 & 80,00 & 93,75 & 87,50 \\
IC 50 & 85,97 & 5 & 5,72 & 80,00 & 83,75 \\
Total & 67,35 & 20 & 38,94 & 1,43 & 98,67 & 87,50 \\
\hline
\end{tabular}


Table 4: The data showed that the EDG incubation time in T47D cell culture gave different viability results and IC ${ }_{50}$ values.

\begin{tabular}{lccc}
\hline \multirow{2}{*}{ Dose $(\mu \mathrm{g} / \mathrm{ml})$} & \multicolumn{2}{c}{ Viabilitas } & 72 hours \\
\cline { 2 - 4 } 15.625 & $\mathbf{2 4}$ hours & $\mathbf{4 8}$ hours & 100.94 \\
31.25 & 101.32 & 100.40 & 102.54 \\
62.5 & 89.45 & 107.34 & 100.40 \\
125 & 69.23 & 98.10 & 77.28 \\
250 & 47.87 & 66.13 & 30.91 \\
500 & 21.19 & 31.20 & 1.65 \\
1000 & 1.91 & 14.37 & 3.31
\end{tabular}

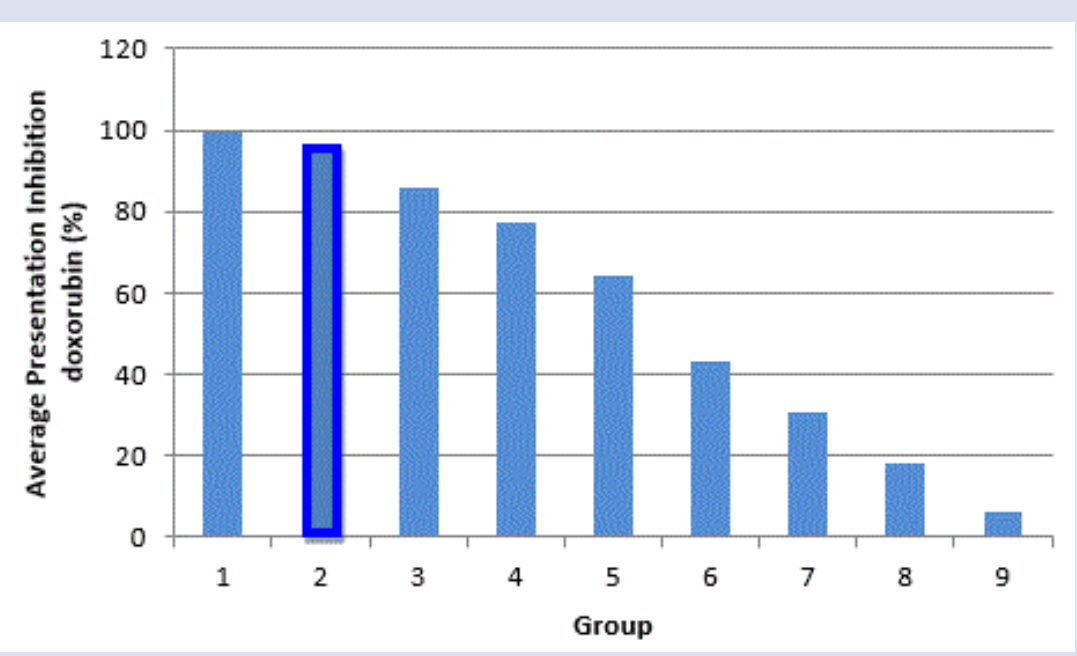

Figure 2: Average percentage inhibition.

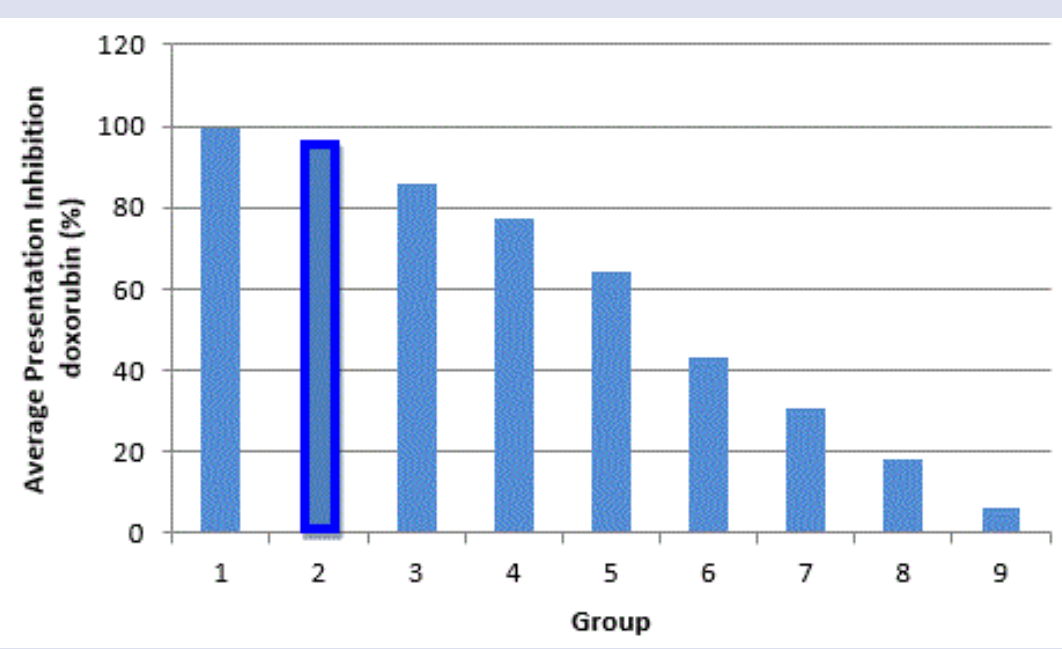

Figure 2: Average percentage inhibition.

\section{Doxorubicin against T47D cells}

Testing of doxorubin drug activity on T47D cell viability was carried out using the ELISA method. The results of testing the viability of T47D cell culture given Doxorubicin with various concentrations obtained data according to table 5 and Figure 5.

Based on table 5 and figure 5 , various $\mathrm{IC}_{50}$ values are obtained. The data showed that the incubation time of Doxorubin in T47D cell culture gave different viability and $\mathrm{IC}_{50}$ values. The longer the incubation period, the smaller the $\mathrm{IC}_{50}$ concentration used to kill T47D cells. The
Doxorubin concentration required to produce $50 \%$ activity after 24 hours incubation obtained $\mathrm{IC}_{50}$ values of $35.02 \mu \mathrm{g} / \mathrm{ml}$; after 48 hours of incubation, the $\mathrm{IC}_{5} 0$ value was $32.55 \mu \mathrm{g} / \mathrm{ml}$; After 72 hours of incubation, the $\mathrm{IC}_{50}$ value was $26.06 \mu \mathrm{g} / \mathrm{ml}$.

Effect of EDG on the Expression of the p53 gene in T47D cells

Observation of the effect of EDG administration on p53 gene expression in T47D cells was carried out using immunohistochemical methods. The results of immunohistochemical staining on T47D cell cultures 


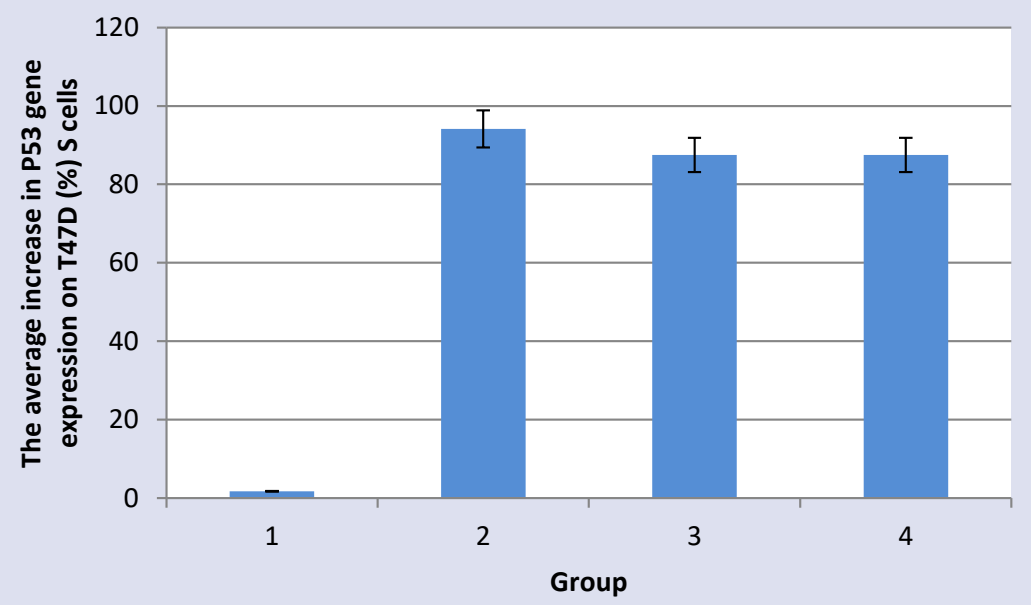

Caption:

Figure 3: The average increase in p53 gene expression on T47D cells.

The same abc superscript showed no difference between groups (based on LSD test) at $\alpha=0.05$

Group 1: negative control group

Group 2: IC10 EDG group

Group 3: IC25 EDG group

Group 4: EDGIC group 50

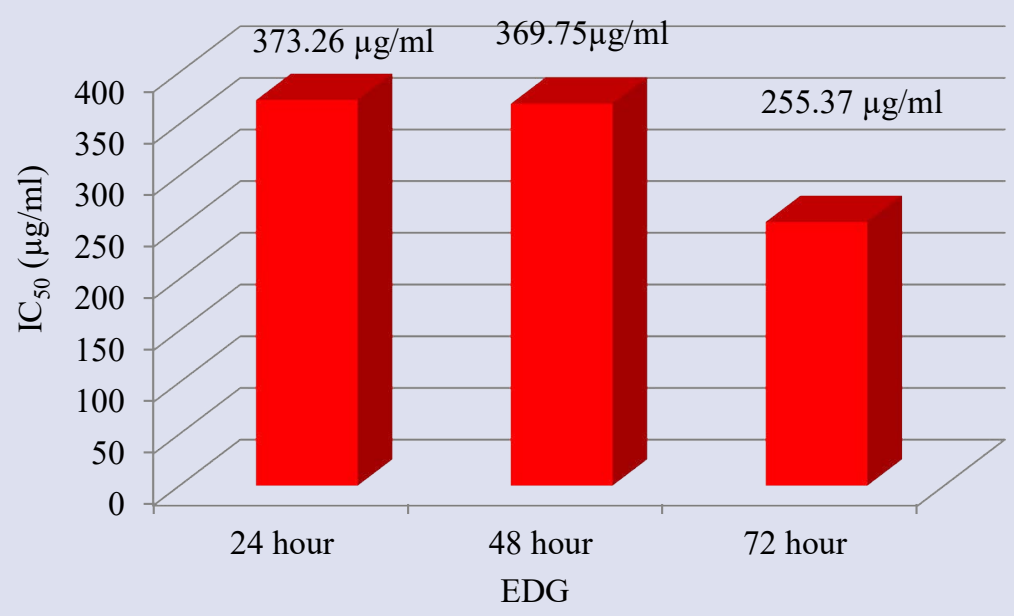

Figure 4: IC50 EDG on T47D Cells.

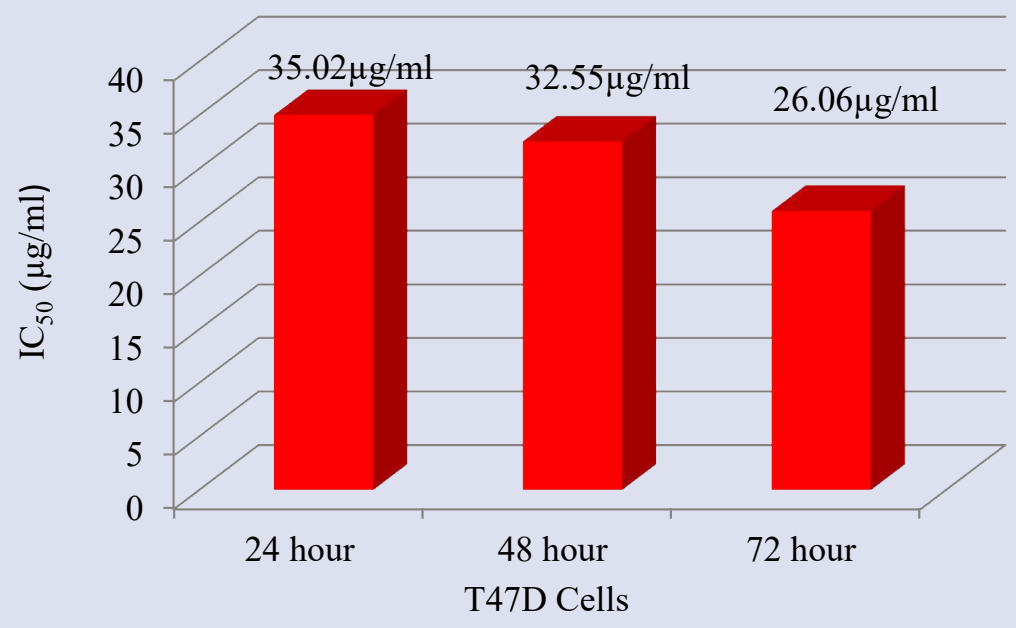

Figure 5: Value of $I C_{50}$ Doxorubicin on T47D Cells. 
Table 5: Results of Testing the Effect of Doxorubicin on the Viability of T47D Cells after 24, 48, and 72 hours of Incubation.

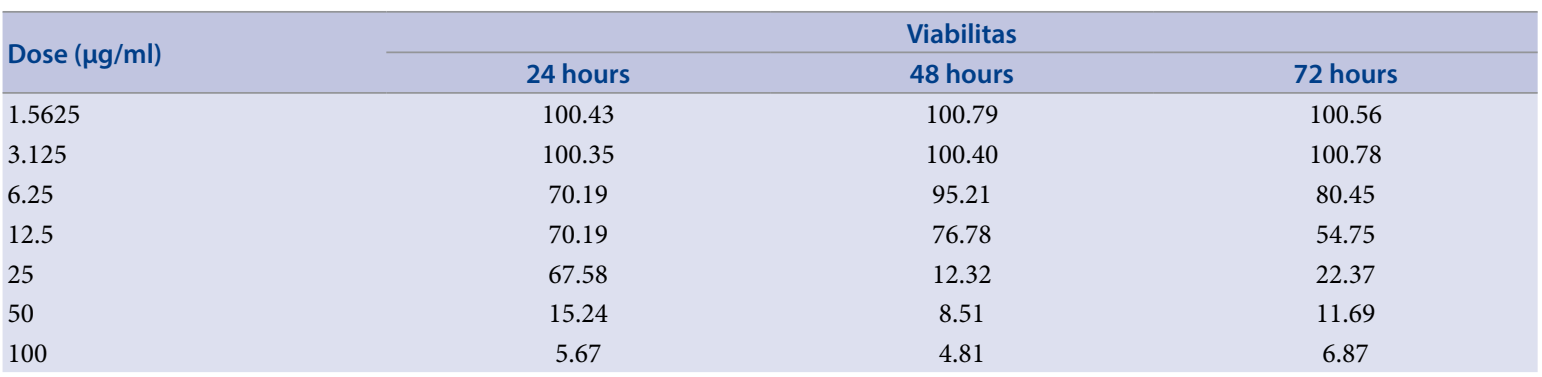

Table 6: Percentage of P53 Gene Expression in T47D Cells After Giving EDG with Several Concentrations.

\begin{tabular}{|c|c|c|c|}
\hline \multirow{2}{*}{ Replication } & \multicolumn{3}{|c|}{ The percentage (\%) of p53 gene expression in T47D cells } \\
\hline & Dose $10 \mu \mathrm{g} / \mathrm{ml}$ & Dose $25 \mu \mathrm{g} / \mathrm{ml}$ & Dose $50 \mu \mathrm{g} / \mathrm{ml}$ \\
\hline 1 & 93.75 & 92 & 8939 \\
\hline 3 & 80.64 & 80 & 95.31 \\
\hline 4 & 80 & 93.75 & 98.66 \\
\hline
\end{tabular}

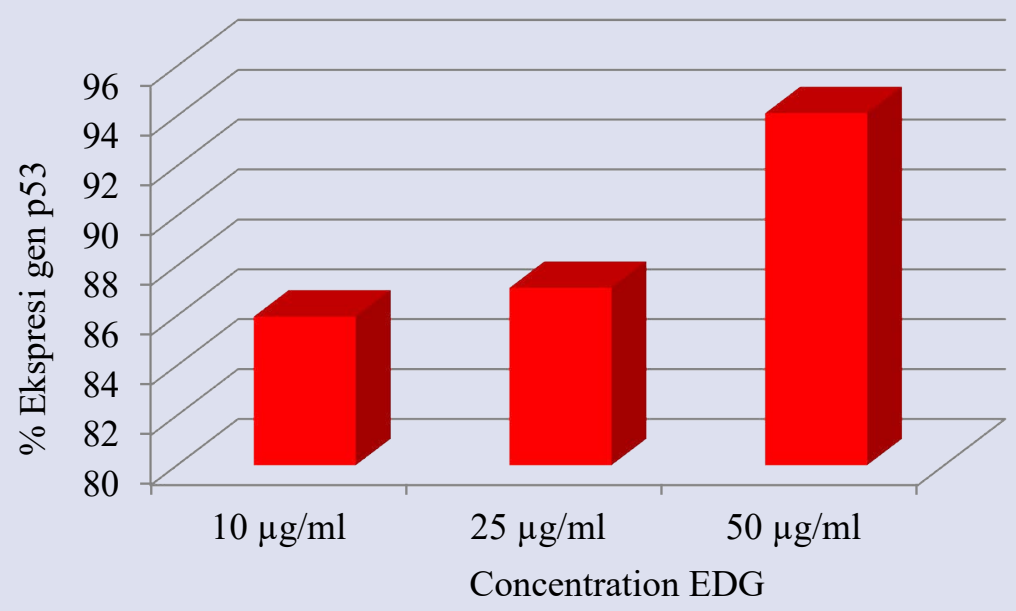

Figure 6: The mean percentage of $\mathrm{p} 53$ gene expression in T47D cells after EDG administration.

given EDG with various concentrations showed a brownish color at the core. These results differ from cells that do not express the p53 gene. Based on the immunohistochemical description, data is obtained according to table 6 and figure 6 .

Based on table 6 and Figure 6, the percentage of T47D cells that express the p53 gene is obtained. The data show that the higher the EDG concentration is given, the greater the T47D cells expressing the p53 gene. The concentration of $10 \mu \mathrm{g} / \mathrm{ml}$ gave activity of $85.97 \% \mathrm{~T} 47 \mathrm{D}$ cancer cells that express the p53 gene. Likewise, a concentration of $25 \mu \mathrm{g} / \mathrm{ml}$ showed $87.12 \%$ and a concentration of $50 \mu \mathrm{g} / \mathrm{ml}$ showed $94.13 \%$ of T47D cancer cells expressing the p53 gene. These data illustrate that EDG has the potential to increase p53 gene expression in T47D cancer cells.

\section{DISCUSSION}

\section{Effect of EDG on the viability of T47D cells}

This test was conducted to determine how much the cytotoxic potential of EDG was against 2 cancer cells, namely T47D and Hela cells in vitro. The method used in this cytotoxic test is the MTT method. The basis for measuring the MTT method is the measurement of the formazan crystals formed. Formazan crystals are purple crystals that are water insoluble but $10 \%$ soluble in SDS. The formation of formazan crystals is the result of the reaction between the MTT salt and the tetrazolium succinate reductase system contained in the mitochondria of living cells ${ }^{8}$, so that living cancer cells will be able to form more formazan crystals than dead cancer cells.

The sample in the form of an extract must be sufficiently soluble in a solvent, therefore a solvent that can dissolve it is sought. The solvent chosen in this study is DMSO because it can dissolve inorganic and organic ions. Djajanegara \& Wahyudi (2009) ${ }^{9}$ explained that DMSO is not toxic to cancer cells. The DMSO control used was the highest DMSO concentration used to dissolve the sample.

Observation of the cytotoxic potential of cancer cells is by calculating the percentage of living cells. The concentration of the sample is made in order to obtain a more linear equation, then a linear equation is made between the concentration vs the percentage of living cells. The $\mathrm{IC}_{50}$ value is the concentration that can kill half of the cancer cells. The magnitude of the cytotoxic potential is described by the small $\mathrm{IC}_{50}$ value.

Sample preparation was carried out by dissolving the extract in dimethyl sulfoxide (DMSO) at a level of $250 \mu \mathrm{g} / \mathrm{ml}$ with DMSO $0.3 \%$. 
The use of DMSO is because it is able to dissolve organic and inorganic ions ${ }^{10}$. In previous studies using DMSO up to a concentration of $1.67 \%$ $\mathrm{v} / \mathrm{v}$ did not affect the viability of T47D cells. The sample was then treated with a test solution with 9 concentrations. Furthermore, to facilitate observation, the MTT reagent was used. The dehydrogenase enzyme in cell mitochondria will change the yellow MTT which is water soluble to the formazan which is purple in color which is not water-soluble. The intensity of the purple color indicates the number of active cells that are alive, because the mitochondrial enzymes in active cells metabolize the tetrazolium salt so that the tetrazolium ring is cut by the dehydrogenase enzyme which causes the tetrazolium to turn into formazan ${ }^{11}$. The more purple, the more cells are still alive. After incubation for 4 hours of addition of MTT. The reaction was stopped with SDS (Sodium Dodecyl Sulphate) $10 \%^{11}$.

The addition of SDS as a stooper solution by denaturing the protein into peptide units and forming the SDS-polypetide complex. After the reaction is stopped the purple complex formed is read on the absorption of the ELISA reader with a wavelength of $550 \mathrm{~nm}$. The absorbance obtained is used as a reference for counting living cells.

The effect of EDG administration on the viability of T47D cells was determined based on the number of cells that remained alive after being incubated with EDG with various variations. The extract was administered from a concentration of $31,675 \mu \mathrm{g} / \mathrm{ml}$ to $1000 \mu \mathrm{g} /$ $\mathrm{ml}$. More and more T47D cells were alive, indicating that the EDG concentration given was ineffective. Likewise, the concentration of the extract that gave the T47D cell viability was an effective dose. This is consistent with the statement that cell viability is the number of cells capable of growing in the culture medium. Cell viability is used as a marker of cytotoxicity of a material to determine the biological properties of a material that is toxic to certain cells. One that indicates the cytotoxicity of a substance is a decrease in cell proliferation and a decrease in viability ${ }^{12}$.

The results showed that the longer the incubation period, the smaller the $\mathrm{IC}_{50}$ value was to kill T47D cells. The longer the incubation, the more T47D cells died so that the EDG dose needed to kill T47D cells was getting smaller because the number of living cells had decreased. This means that the use of EDG drugs has the potential to be anti-cancer. In this study, the $\mathrm{IC}_{50}$ value of EGD on the viability of T47D cells was obtained at $255.37 \mu \mathrm{g} / \mathrm{ml}$ after 72 hours of incubation. This means that the dose of $255.37 \mu \mathrm{g} / \mathrm{ml}$ is quite effective in killing T47D cells. EDG activity in killing cancer cells is thought to be related to the content of active substances such as flavonoids. This is in accordance with the mechanism of flavonoid compounds that can inhibit proliferation through inhibition of oxidative processes that can lead to cancer initiation. This mechanism is mediated by the reduction of the enzymes xanthine oxidase, cyclooxygenase (COX) and lipooksidenase (LOX) which are required in the prooxidation process, thereby delaying the cell cycle ${ }^{13}$. Activity in inhibiting the growth of cancer cells, namely flavonoids activate the apoptotic pathway of cancer cells by releasing the proximal DN chain.

\section{Effect of EDG on p53 gene suppression in T47D cells}

The results of observing the effect of EDG administration on p53 gene expression in T47D cells showed that cells expressing the p53 gene were brown in color at the core. These results differ from cells that do not express the p53 gene. The data show that the higher the EDG concentration is given, the greater the T47D cells that express the p53 gene. So it can be stated that EDG has the potential to increase p53 gene expression in T47D cancer cells. The expression of the p53 gene in brown cells appears to be a p53 gene with a wild type in the cytoplasm that plays a role in cell apoptosis ${ }^{14}$

The increase in p53 gene expression in T47D cells indicates that there has been apoptosis or death in these cells. In the study, it was found that EDG has the potential to cause apoptosis in T47D cancer cells at a concentration of $10 \mathrm{ppm}-50 \mathrm{ppm}$. EDG $50 \mathrm{ppm}$ has potential as apoptosis of T47D cells because the number of cells that express the p53 gene is $94.13 \%$. In the event of apoptosis, the P53 gene is expressed when there is DNA damage so that an error occurs in the cell cycle, namely the P53 gene induces cell cycle arrest. This is so that the DNA damage in the damaged cells has time to be repaired. However, if the damage cannot be repaired, the expression of the P53 gene will increase so that it will trigger the apoptosis of T47D cells ${ }^{6}$. Conversely, if the p3 gene is not expressed in cells, a mutation occurs in p53 so that the gene becomes unstable and subsequently has the potential to become cancer. The p53 gene is an apoptotic signal because it suppresses tumor formation and inhibits malignant progression. The mechanism that occurs in cells is that the p53 gene eliminates cells that have DNA damage that has the potential to become cancer cells by means of cell cycle arrest, apoptosis or repair?

The results of the Tests of Normality showed the normality of data from 4 treatment groups (negative control; $\mathrm{IC}_{10} ; \mathrm{IC}_{25} ; \mathrm{IC}_{50}$ ) on the T47D cell variable. All groups showed normally distributed data with a sig value. $0.081-0.959>0.05$. The results of the Kruskal-Wallis test showed that there were differences in the data of the treatment group on the variable increasing $\mathrm{p} 53$ gene expression on T47D cells with a sig value. 0.002 $<0.05$. Mann-Whitney test results showed no difference in the increase in p53 gene expression on T47D cells between EDG treatment IC $_{25}$ and $\mathrm{IC}_{50}(\mathrm{p}=0.456)$.

Nggorang Leaves Extract (EDG) has the potential to be anti-proliferative against cancer cells T47D IC ${ }_{50}=201 \mathrm{ppm}$. Nggorang Leaves Extract (EDG) has the potential to increase p53 gene suppression in T47D cancer cells by $94.13 \%$ at a concentration of $50 \mathrm{ppm}$.

\section{CONCLUSION}

Nggorang Leaves Extract have the potential to be anti-proliferative against cancer cells T47D and has the potential to increase p53 gene suppression in T47D cancer cells.

\section{AUTHORS CONTRIBUTIONS}

All authors contributed equally in this study, and it was in compliance with journal authorship policy. Sisilia Teresia Rosmala Dewi as main authors, and the others (M. Sabir, Sesilia Rante Pakadang, Sainal Edi Kamal and Santi Sinala) were co-authors which helped in every step. Then Santi Sinala as corespondent author.

\section{CONFLICTS OF INTEREST}

Declared none.

\section{REFERENCE}

1. Waty, D. R., Saputri, F. C., \& Mun'im, A. (2017). Secondary Metabolites Screening and Acute Toxicity Test of Peperomia pellucida (L.) Kunth Methanolic Extracts. International Journal of PharmTech esearch, 10(1), 31-38. https://doi.org/10.20902/ijptr.2017.1014

2. Jumar (2010). Daya proteksi minyak atsiri zodia (euvodia suaveolens) dalam bentuk spray terhadap tempat hinggap nyamuK Aedes aegypti L . DAN Culex quinquefasciatus Protection from Essential Oil of Zodia (Euvodia suaveolens ) in Spray Type to Perch of Aedes aegypti L. 2006, 278-282.

3. Bray, F., Ferlay, J., Soerjomataram, I., Siegel, R. L., Torre, L. A., \& Jemal, A. (2018). Global cancer statistics 2018: GLOBOCAN estimates of incidence and mortality worldwide for 36 cancers in 185 countries. CA: A Cancer Journal for Clinicians, 68(6), 394-424. https://doi.org/10.3322/caac.21492

4. Damaris' research (2019), Identifikasi Kandungan Kimia Daun Nggorang (Salvia occidentalis Sw.) menggunakan Spektrofotometer GC-MS. KTI Jurusan Farmasi Sandi Karsa. 
5. Rotter, 2002. Expression of the wild type p53 tomor suppressor gene in normal cells and its deregulation in cancer cells. Departement of Molecular Cell Biology : p:176-177.

6. Hanahan and Weinberg, 2000 The Hallmarks of Cancer, Cell, 100: 57-70.

7. Hietanen et al, 2000; , Health Physics: November 2000 - p S77-S84.

8. Doyle \& Griffiths, 2000 Cell and Tissue Culture for Medicinal Research. John and Wiley Sons, New Jersey, 567-569.

9. Djajanegara \& Wahyudi (2009) Pemakaian Sel Hela dalam Uji Sitotoksisitas Fraksi Ethanol Biji Mimba (Azadirachta indica) Majalah Ilmiah Biologi Journal.bio.unsoed.ac.id.
10. Fessenden \& Fessenden, 1994 Organic chemistry California, Cole Publishing Inc.

11. Suhendi A, Haryoto, P Idrayudha, T Azizah, 2013. Aktivitas Sitotoksik Ekstrak Etanol Tumbuhan Sala (Cynometraramiflora L) tehadap Sel Hela, T47D, dan WiDR, Skripsi Universitas Surakarta.

12. Freshney, 2000. Animal cell culture, A practical approach. 1 st ed Washington DC:IRL Press;p.3. 38, 83-8, 309412,329-30,336-7.

13. Ren, W., Qiao, Z., Wang, H., Zhu, L., \& Zhang, L. (2003). Flavonoids: Promising anticancer agents. Medicinal Research Reviews, 23(4), 519-534. https://doi.org/10.1002/med.10033.

14. Matlashewsky, 1999. P53. Twenty years on, Meeting Review, Oncogene, 18:7618-7620.

\section{GRAPHICAL ABSTRACT}

\section{GRAPHIG ABSTRAGT}

Anti-Cancer Potential of Nggorang Leaves Extract

(Salvia occidentalis SW.) as a Protein P53 Supressor

in T47D Cells
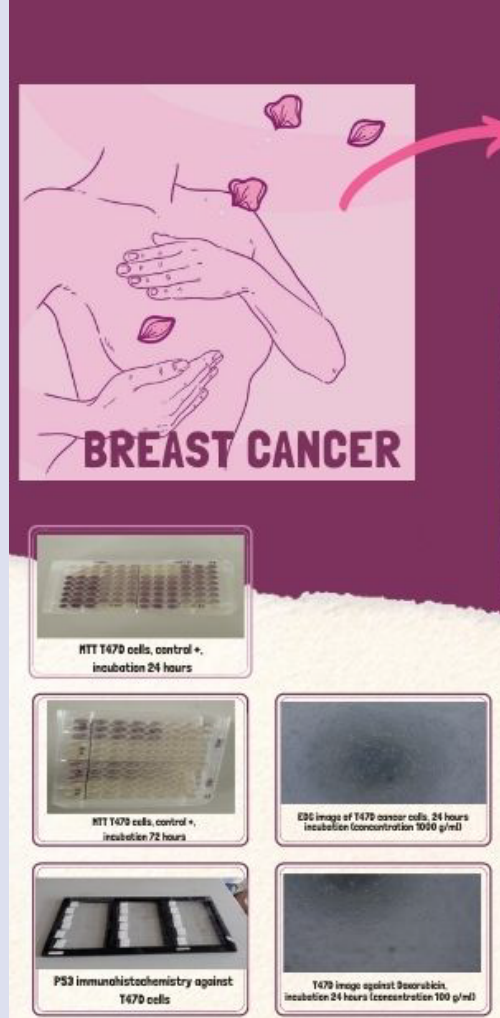

\section{( A Anticancer from} Natural Ingredients
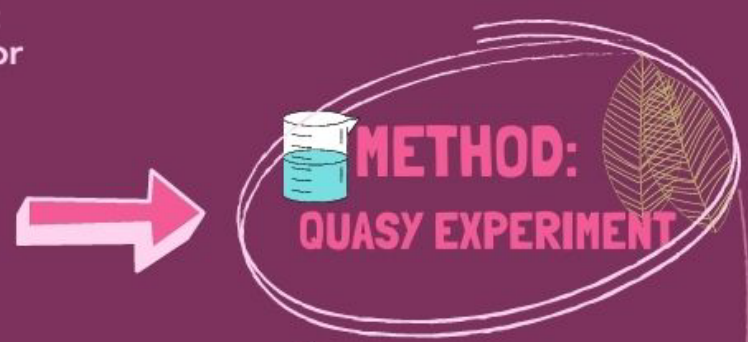

NGGORANG LEAVES

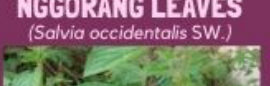

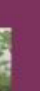
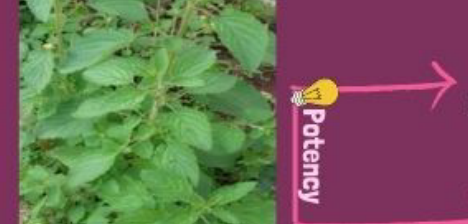

EDG CNggorang Leaves

Extract) as an antiproliferative against hela cancer cells
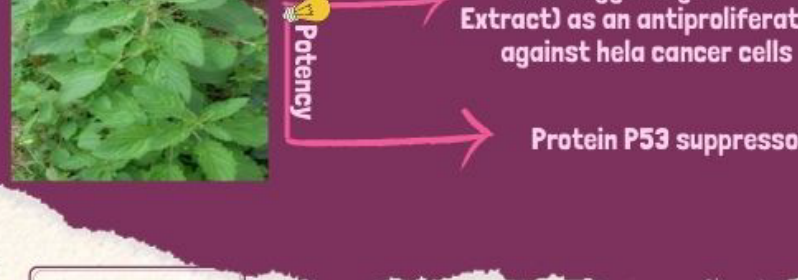

Protein P53 suppressor
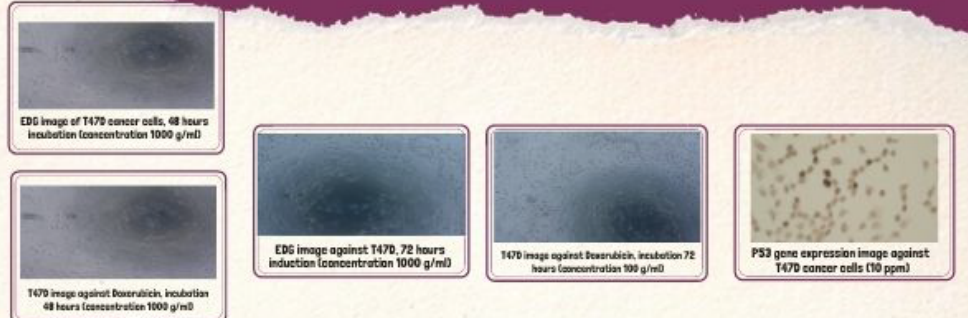


\section{ABOUT AUTHORS}

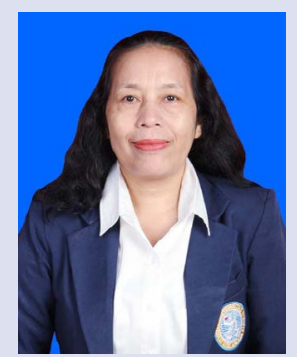

Dr. Sisilia Teresia Rosmala Dewi, M.Kes, Apt was born Kumba, October, 03, 1970. Doctoral education is completed at Airlangga University. A lecturer and researcher from East Nusa Tenggara. Her current research is the development of traditional medicine, one of the plants from where she was born, which is used by the public as an anti-breast cancer. Active as a lecturer in the Department of Pharmacy especially Pharmacology, Health Polytechnic Makassar of Ministry Health Republic of Indonesia. Has produced several publications and books.

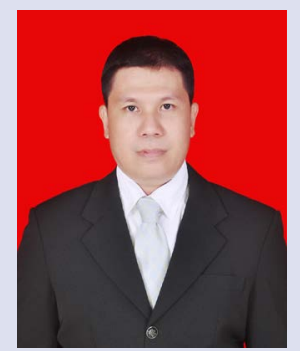

Dr.dr. M. Sabir, M.Si, is a lecturer as well as a doctor. He is currently the head of the faculty of the Faculty of Medicine, Tadulako University, Palu, Indonesia. Has completed his doctoral studies in Hasanuddin University, Makassar, Indonesia 2014. Active as a researcher in the field of medicine and has published many research in national and international journals. Has attended many scientific meetings both nationally and internationally.

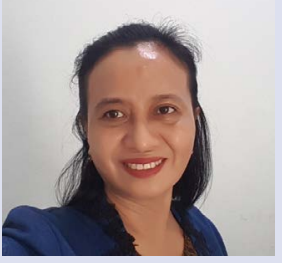

Dr. Sesilia Rante Pakadang, M.Si, Apt was born in Sinjai, September 22, 1969. She studied from bachelor to master at Hasanuddin University. Doctoral education is completed at Airlangga University. Have expertise in the field of Microbiology. Now as a permanent lecturer in the Department of Pharmacy Health Polytechnic Makassar of Ministry Health Republic of Indonesia. The research focuses on traditional medicine as it is today, which is knowing more about the efficacy of Miana Plant. Active as a researcher and has published many articles.

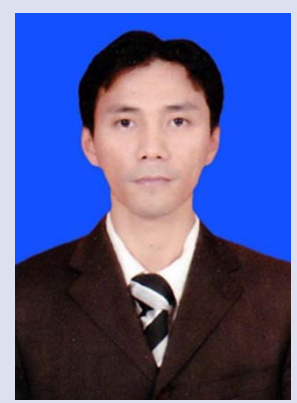

Sainal Edi Kamal, S.Si, M.Kes, Apt is a lecturer at Polytechnic Sandi Karsa Makassar Indonesia. Focuses on Pharmacology and is active as a researcher and has attended several scientific meetings as an oral speaker. The results of the research have been published in several national journals.

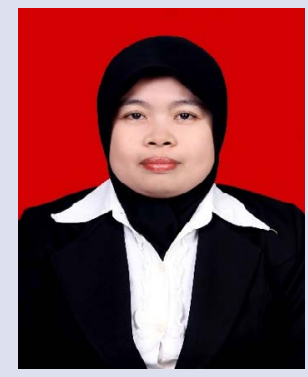

Santi Sinala, S.Si, M.Si., Apt, was born in Palopo, September 28, 1983. Currently a permanent lecturer in the Department of Pharmacy, Health Polytechnic Makassar of Ministry Health Republic of Indonesia, and teaches several courses in the fields of Pharmacognition and Phytochemistry and Physics Pharmacy. Now, teaching in pharmaceutical technology. The author is active as a researcher in the field of Pharmacy and productively produces as many as 11 scientific articles that have been journalized. Has produced Phytochemistry textbook, Physics Pharmacy Module, Physics Practicum Guide that has been in IPR right. Active as an oral speaker at two international conferences.

Cite this article: Dewi STR, Sabir M, Pakadang SR, Kamal SE, Sinala S. Anti-Cancer Potential of Nggorang Leaves Extract (Salvia Occidentalis SW.) as a Protein P53 Supressor in T47D Cells. Pharmacogn J. 2021;13(4): 1036-1045. 